\title{
RULE BASED ACCOUNTING STANDARDS VS PRINCIPLE BASED ACCOUNTING STANDARDS: A Critical Examination on Selected Sri Lanka Accounting Standards
}

By

\begin{abstract}
AMJ Attanayake GS/MC//11266/2000
\end{abstract}

\begin{abstract}
A dissertation
Submitted to the University of Sri Jayewardenepura In partial fulfilment of the requirement for the degree of Master of Science in Management
\end{abstract}

M.Sc (Management) Program

Faculty of Graduate Studies

University of Sri Jayewardenepura

Jully 2006 


\section{AUTHOR'S DECLARATION}

The work described in the thesis was carried out by me under the supervision of Prof.MW Wickramarachchi and a report on this has not been submitted in whole or in part to any university or any other institution for another Degree/Diploma.

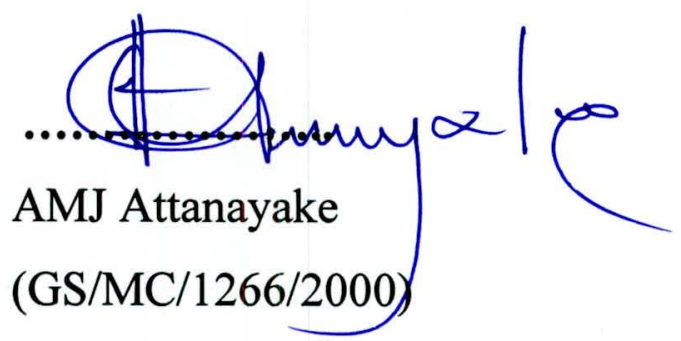

Author 


\section{CERTIFICATION}

I hereby recommend that the thesis was prepared under my supervision

By

AMJ Attanayake

(GS/MC/1266/2000)

\section{Entitled: RULE BASED ACCOUNTING STANDARDS VS PRINCIPLE BASED ACCOUNTING STANDARDS: A Critical Examination on Selected Sri Lanka Accounting Standards}

Accepted in partial fulfilment of the requirements for the degree of Master of Science in Management.

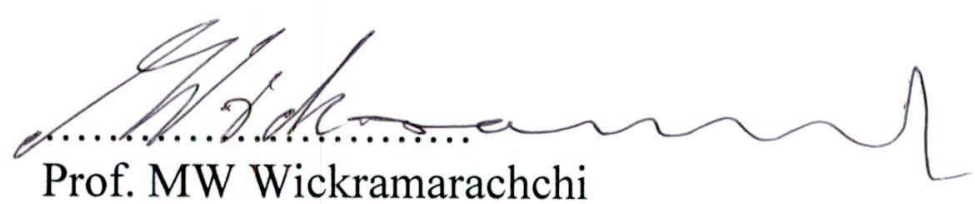

Thesis Advisor

Approved by the Examining Committee

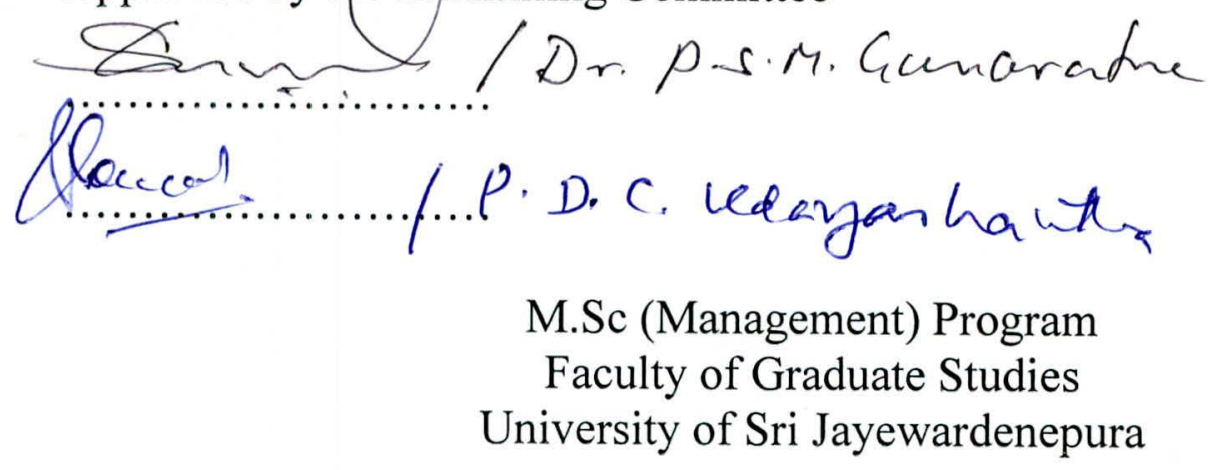

July 2006 


\section{ACKNOWLEDGEMENT}

First and foremost, I am indebted to Prof. MW Wickramarachchi, Senior Lecturer, Department of Accounting, University of Sri Jayewardenepura who supervised the study by giving insight, valuable advices, guidance, inspirations and generous scarification of his valuable time, leaving his obligatory commitments away with incredible humility in spite of his busy schedules in the university.

I would also like to thank Dr.Sampath Amarathunge, the early coordinator in the M.Sc Degree Program Unit, for his genuine interest, understanding and the kindness extended towards the success of students and to the present coordinator Dr PD Nimal for his courteous support.

I wish to offer my sincere thanks to Prof. David Alexander, Professor in Accounting, University of Birmingham, who developed the world accepted definition for Principle Based Accounting Standards, for sending his latest studies with valuable comments and Mr. PJ Jayathilake, Head Department of Business Management, University of Sabaragamuwa, for his continuous support. A special thanks due to my colleague, Mr. H.G Piyasiri who split his intellectuality generously for the success of the study.

My heartfelt thanks go to Mr.NRP.Alexander, who taught me the alphabet of accounting, at the Passara Central College and Mr.Ashoka Jayasinghe, Senior Partner, Jayasinghe \& Company, Chartered Accountants, who enlighten my professional life in accounting.

Without the help, moral support, and care with patience of my wife, Kanthi and my little Hiru who taught me the life, I could not have completed this in time. I acknowledge their wholehearted support with thanks.

If you have not scarified your whole life for me, my dear parents, this would not have become a reality. Therefore I dedicate honestly the results of entire effort to you. 


\section{ABSTRACT}

\section{Rule Based Accounting Standards Vs Principle Based Accounting Standards: A Critical Examination on Selected Sri Lanka Accounting Standards}

Debacle of Enron and the other large accounting scandals in the world placed the accounting professionals in a verge of dilemma with a debate of Rule Based Accounting Standards vs. Principles Based Accounting Standards. The challenge was constituted by the Sarbanes-Oxley Act of 2002 designating the Security Exchange Commission (SEC) to submit a study report to the US congress on the feasibility of steering towards the Principle Based Accounting Standards from Rule Based Accounting Standards.

The purpose of the study was to become aware of whether the Sri Lanka Accounting Standards (SLAS) contained the characteristics of Rule Based Accounting Standards and to assess the appropriateness of the provisions of SLAS which include such characteristics in terms of the definition of Principle Based Accounting Standards.

Based on the articulated definition of Rule Based Accounting Standards and Principle Based Accounting Standards, selected SLAS were examined critically with a holistic perspective.

The study revealed that all examined SLAS contained a substantial amount of Specific Criteria, Examples, Exceptions, Subsequent Precedents, Implementation Guidelines and Determinate Rules. In Addition, the study ascertained that they also contained a considerable number of Bright-line Thresholds and few Scope Restrictions.

The study concluded that all the characteristics of Rule Based Accounting Standards included in the SLAS should be eliminated to the extent possible, leaving an ample scope for the exercise of professional judgment. And the study recommended embodying the provisions to the SLAS which represent the reality with true and fair reflection of economic substance of Objective Based Accounting Standard. 


\section{TABLE OF CONTENTS}

Acknowledgement I I

Abstract II

Table of Content III

List of Table $\quad$ IX

List of Figures $\quad \mathrm{X}$

$\begin{array}{lr}\text { CHAPTER ONE: Introduction } & 01-07\end{array}$

$\begin{array}{ll}1.1 \text { Background } & 01\end{array}$

$\begin{array}{ll}1.2 \text { Research Problem } & 01\end{array}$

1.3 Objectives of the Study 02

1.4 Justification 03

$\begin{array}{ll}1.5 \text { Limitation of the Study } & 04\end{array}$

1.6 Concepts \& Terms 04

$\begin{array}{ll}1.7 \text { Research Methodology } & 05\end{array}$

1.7.1 Research Design 05

1.7.2 Sample 06

1.7.3 Method of Data Collection $\quad 06$

1.7.4 Data Analysis $\quad 06$

$\begin{array}{ll}1.8 \text { Structure of the Final Report } & 07\end{array}$

$\begin{array}{lr}\text { CHAPTER TWO: Literature Review } & 08-42\end{array}$

2.1 Preamble 08

2.2 Review of Prior Studies $\quad 09$

2.2.1 Schipper, K. (2003) Principle Based Accounting 09 Standards 
2.2.1.1 Objective of this study

2.2.1.2 Methodology and the summary of contents

2.2.1.3 Conclusions and comments

2.2.2 Nobes, C. (2005) Rule Based Standards and the lack of

Principles in Accounting

2.2.2.1 Objective of this study

2.2.2.2 Methodology and the summary of contents

2.2.2.3 Conclusions and comments

2.2.3 Nelson, M.W., (2003). Behavioural Evidence on the

Effects of Principles and Rule Based Standards

2.2.3.1 Objective of this study

2.2.3.2 Methodology and the summary of contents

2.2.3.3 Conclusions and comments

2.2.4 Staubus, G.J., (2004) On Brian P. West's Professionalism 13 And Accounting Rules

2.2.4.1 Objective of this study

2.2.4.2 Methodology and the summary of contents

2.2.4.3 Conclusions and comments

2.2.5 Boone, J.P. and K.K.Raman., (2004) Principle vs. Rules

Based Standards; Does Accounting Discretion Increase the Quality of the Reported Earnings.

2.2.5.1 Objective of this study

2.2.5.2 Methodology and the summary of contents

2.2.5.3 Conclusions and comments

2.2.6 Webster, E. and D.B.Thornton., (2004) Earning Quality 16 Under rules -vs. Principle Based Accounting Standards

: A Test of the Skinner Hypothesis

2.2.6.1 Objective of this study

2.2.6.2 Methodology and the summary of contents 
2.2.7 Warnock, K., (1997) On the Nature of Rules in Accounting

2.2.7.1 Objective of this study

2.2.7.2 Methodology and the summary of contents

2.2.7.3 Conclusions and comments

2.2.8 Ijiri, y., (2005) US Accounting Standards and Their 18 Environment: A Dualistic Study of Their 75-Years of Transition

2.2.8.1 Objective of this study 18

2.2.8.2 Methodology and the summary of contents 18

2.2.8.3 Conclusions and comments

2.2.9 Shortridge, R.T. and M. Myring., (2005) Defining

Principles-Based Accounting Standards.

2.2.9.1 Objective of this study

2.2.9.2 Methodology and the summary of contents

2.2.9.3 Conclusions and comments

2.2.10 Alexander, D. and Jermakowicz, E.K. (2005). A True and 22 Fair View of the Principles/ Rules Debate.

2.2.10.1 Objective of this study

2.2.10.2 Methodology and the summary of contents

2.2.10.3 Conclusions and comments

2.2.11 Levin, J.A., (2004) Issues Relevant to New Accounting

Standards in a Compliance Programme.

2.2.11.1 Objective of this study

2.2.11.2 Methodology and the summary of contents

2.2.11.3 Conclusions and comments

2.2.12 Levit, A. (1998) The Importance of High Quality

Accounting Standards

2.2.12.1 Objective of this study 
2.2.12.2 Methodology and the summary of contents

2.2.12.3 Conclusions and comments

2.2.13 Amenic, J. and R. Craig., (2004) Reform in Accounting

Education in the Post-Enron Era: Moving accounting

"Out of Shadows"

2.2.13.1 Objective of the study

2.2.13.2 Methodology and the summary of contents

2.2.13.3 Conclusions and comments

2.2.14 Choi, Y.C. and I.N. McCarthy (2003) FASB Proposes

Principle-Based Approach to US Standards Setting.

2.2.14.1 Objective of the study

2.2.14.2 Methodology and the summary of contents

2.2.14.3 Conclusions and comments

2.2.15 Reither, C.L. (1997) How the FASB Approaches A

Standard Setting Issue.

2.2.15.1 Objective of the study

2.2.15.2 Methodology and the summary of contents

2.2.15.3 Conclusions and comments

CHAPTER THREE:Debate of Rule Based Accounting and Principle

\section{Based accounting:}

3.1 Introduction

3.2 Criticisms of Rule Based Approach to Accounting

3.3 Rationalization of Rule Based Accounting 


\section{Accounting Standards and Principle Based}

\section{Accounting Standards}

4.1 Definitions of Principle Based Standards and Rule Based Standards 70

4.1.1 Principle Based Accounting Standards $\quad 70$

$\begin{array}{ll}\text { 4.1.2 Rule Based Accounting Standards } & 72\end{array}$

4.2 A Review of Some Specific Accounting Standards 73

4.2.1 Sri Lanka Accounting Standard SLAS 5 (Revised 2005) 73

: Inventories

4.2.2 Sri Lanka Accounting Standard SLAS 18 (Revised 2005) 74

: Property, Plant \& Equipment

4.2.3 Sri Lanka Accounting Standard SLAS 20: Borrowing Costs 74

4.2.4 Sri Lanka Accounting Standard SLAS 22: Accounting for 75 Investments

4.2.5 Sri Lanka Accounting Standard SLAS 23: Revenue

Recognition and Disclosures in the Financial Statements of Banks

4.2.6 Sri Lanka Accounting Standard SLAS 24: Accounting For

Government Grants and Disclosure of Government

Assistance

4.2.7 Sri Lanka Accounting Standard SLAS 25: (Revised 2004)

Business Combinations

4.2.8 Sri Lanka Accounting Standard SLAS 26

:( Revised 2005) Consolidated and Separate Financial

Statements

4.2.9 Sri Lanka Accounting Standard SLAS 37: Intangible Assets 83

4.2.10Sri Lanka Accounting Standard SLAS 41: Impairment 85 of Assets 
5.1 Motivation to Study and Objectives 87

5.2 Findings and Recommendations 88

5.2.1 Specific conclusions 88

5.2.2 General Conclusions 89

5.2.3 Recommendations 89

5.3 Further Developments 90

REFERENCES $91-96$ 


\section{LIST OF TABLES}

Page

2.1 Three Levels of Accounting and Financial Reporting

Regulations

4.1 Assessment of SLAS in Terms of Rule Based

Characteristics 


\section{LIST OF FIGURES}

\section{Page}

2.1 Simplified Schemes of IASB Concepts

2.2 Hierarchies of Accounting Qualities 


\section{CHAPTER ONE}

\section{INTRODUCTION}

\subsection{Background}

At present there are many discussions about rule based accounting standards and principle based accounting standards. With the expansion of industry and business during the last century, the discipline of accounting evolves through setting standards.

The process of setting accounting standards was highly criticized at the debacle of Enron. The Accounting profession and the governing bodies of accounting were also highly accused and criticized in terms of setting accounting standards through lengthy rules. Especially Security Exchange Commission (SEC) in USA and investors urged to take up principle based revamp moving towards a principle based standards setting process, cutting cumbersome lengthy rules. In the Financial Times of $10^{\text {th }}$ February, Professor Niall Lothian is quoted as saying that accountants who do not have degrees in accountancy are driven to look up the cookbook of instructions rather than thinking through the issues. Professor David Hatherly is quoted as stressing the need for a profession sure of its own thought process and not seeking refuge in rules. In response to these concerns, growing number of stakeholders and Security Exchange Commission of USA endorsed the adoption of broader principle based standards replacing rule based standards.

\subsection{Research Problem}

After big accounting scandals like Enron, WorldCom, Global Crossing, Tyco and Adelphi, regulatory mechanisms of accounting in USA, UK and the other countries intensified the scrutiny of accounting standards to see whether their accounting standards are rule based or principle based. 
When a country's accounting standards contain characteristics of rule based accounting standards such as specific criteria, bright-line thresholds, examples, scope restrictions, exceptions, subsequent precedents, implementation guidelines, determinants and indeterminate rules it tends to stray the professionalism because rules in accounting reduce the scope of professionals exercising a professional judgement. No profession could survive the imposition of rigid code of rules and regulations rather than relying on the exercise of judgment in the application and determination of methods and procedures to achieve an objective. Especially the accounting profession will not serve the public interest by confining its practitioner's stand-in rule based accounting standards which does not ensure the primacy of true and fair view and economic substance. The professional accountants in Sri Lanka are bounded by the law and practice to apply The Sri Lanka Accounting Standards (SLAS) which are based on International Accounting Standards(IAS), constitute by The Institute of Chartered Accountants of Sri Lanka(ICASL). A key contemporary query which has to find clarification in Sri Lanka is that the present SLAS contain rules.

\subsection{Objectives of the Study}

The overall objective of the study is to examine the selected Sri Lanka Accounting Standards to see whether they contain rules with reference to the characteristics of rule based accounting standards and principle based accounting standards. In the study, the researcher expects to achieve the following specific objectives;

1. To identify the characteristics of rule based accounting standards such as specific criteria, bright-line thresholds, examples, scope restrictions, exceptions, subsequent precedents, implementation guidelines, determinants and indeterminate rules in the selected SLAS.

2. To assess the appropriateness of provisions of SLAS which contain the characteristics of rule based accounting standards with reference to the characteristics of principle based accounting standards. 